\title{
The significance of secukinumab in the treatment of plaque psoriasis
}

\section{Znaczenie sekukinumabu w leczeniu łuszczycy plackowatej}

Marta Kasprowicz-Furmańczyk, Agnieszka Owczarczyk-Saczonek

The Municipal Polyclinic Hospital, Olsztyn, Poland

Miejski Szpital Zespolony, Olsztyn, Polska

Dermatol Rev/Przegl Dermatol 2021, 108, 372-384

DOI: https://doi.org//0.5 | |4/dr.2021.1 I3 55

\author{
CORRESPONDING AUTHOR/ \\ ADRES DO KORESPONDENCJI: \\ lek. Marta Kasprowicz- \\ -Furmańczyk \\ Miejski Szpital Zespolony \\ Olsztyn, Polska \\ tel.: +48784092806 \\ e-mail: martak03@wp.pl
}

\begin{abstract}
Psoriasis is a chronic inflammatory skin disease that affects approximately $1-3 \%$ of the general population in Poland. It is estimated that in $70-80 \%$ of patients skin lesions are mild and require only topical medications. In severe plaque psoriasis, classic treatments often lead to a loss of efficacy, adverse effects or insufficient treatment effect, therefore it is necessary to search for new therapeutic methods. Multiple studies show that secukinumab, a fully human monoclonal antibody that selectively neutralizes interleukin-17A (IL-17A), has significant efficacy in the treatment of moderate to severe psoriasis, demonstrating a rapid onset of action and sustained response with a good safety profile. The role of secukinumab in the treatment of plaque psoriasis is discussed in this article.
\end{abstract}

Key words: secukinumab, psoriasis, biological treatment.

\section{STRESZCZENIE}

Łuszczyca jest przewlekłą chorobą zapalną skóry dotyczącą ok. 1-3\% populacji ogólnej w Polsce. Szacuje się, że u 70-80\% chorych zmiany skórne mają niewielkie nasilenie i wymagają stosowania jedynie leków miejscowych. W przypadku ciężkiej łuszczycy plackowatej w wyniku stosowania klasycznych metod leczenia często dochodzi do utraty skuteczności, wystąpienia działań niepożądanych lub niewystarczającego efektu terapii, dlatego też niezbędne jest poszukiwanie nowych metod terapeutycznych. Liczne badania wykazują, że sekukinumab w pełni ludzkie przeciwciało monoklonalne, selektywnie neutralizujące interleukinę 17A (IL-17A) ma znaczącą skuteczność w leczeniu umiarkowanej do ciężkiej łuszczycy, wykazując szybki początek działania i trwałe odpowiedzi o korzystnym profilu bezpieczeństwa. W artykule omówiono znaczenie sekukinumabu w leczeniu łuszczycy plackowatej.

Słowa kluczowe: sekukinumab, łuszczyca, leczenie biologiczne. 
Psoriasis is a chronic inflammatory skin disease that affects approximately $1-3 \%$ of the general population in Poland [1]. It is estimated that in $70-80 \%$ of patients skin lesions are mild and require only topical medications. In case of a severe course, it is advisable to implement phototherapy or general therapy in order to achieve remission. According to the latest reports, approximately $5-30 \%$ of psoriasis patients have psoriatic arthritis (PsA). The diagnosis of the comorbidity of psoriasis and PsA is important to therapeutic strategies, but it is often delayed or overlooked [2]. Conventional methods of treatment often lead to a loss of effectiveness, adverse effects or insufficient treatment effect, therefore it is necessary to search for new therapeutic methods. Multiple studies show that secukinumab, a fully human monoclonal antibody that selectively neutralizes interleukin-17A (IL-17A), has significant efficacy in the treatment of moderate to severe psoriasis, PsA and ankylosing spondylitis with rapid onset of action and sustained responses with a favorable safety profile.

\section{PATHOGENESIS OF PSORIASIS AND THE IMPORTANCE OF INTERLEUKIN-I 7 (IL-I7) IN THE DEVELOPMENT AND COURSE OF THE DISEASE}

The current state of knowledge on the pathogenesis of psoriasis suggests a key role of the IL-23/ Th17/IL-17 axis in initiating the inflammatory process in psoriasis, referred to as "autoinflammation". The Th1/IFN- $\gamma$ axis and pro-inflammatory cytokines (such as TNF) are dominant only in the chronic phase of the disease [3]. Identification of T-17 helper cells (Th17) in psoriatic plaques indicated the T-cell population as a key contributor to the pro-inflammatory state of psoriasis. In response to the action of several cytokines, including IL-1 $\beta$, IL-6, transforming growth factor $\beta$ (TGF- $\beta$ ), CD4 + T cells differentiate into Th17 cells, the survival and activation of which are mainly controlled by IL-23. Exposure of nascent Th17 cells to IL-23 increases the production of other effector cytokines, i.e., IL-17A, IL-17F, IL-22 and tumor necrosis factor (TNF). Thus, the production of IL-17 is closely related to and dependent on the presence of IL-23. Interestingly, IL-17 may also be secreted by mast cells, neutrophils, cytotoxic T cells, and NK cells [4]. The IL-17 family of cytokines consists of six members (IL-17A to IL-17F), of which IL-17A is the primary effector cytokine of the Th17 cell line. IL-17 cytokines perform their biological functions by binding to the appropriate transmembrane receptor (IL-17R), which is a heterodimer composed of five different

\section{WPROWADZENIE}

Łuszczyca jest przewlekłą chorobą zapalną skóry, która dotyczy ok. 1-3\% populacji ogólnej w Polsce [1]. Szacuje się, że u 70-80\% chorych zmiany skórne mają niewielkie nasilenie i wymagają stosowania jedynie leków miejscowych. W przypadku ciężkiego przebiegu wskazane jest wdrożenie terapii ogólnej w celu uzyskania remisji choroby. Według najnowszych doniesień u około 5-30\% pacjentów z łuszczycą stwierdza się łuszczycowe zapalenie stawów (ŁZS). Rozpoznanie współwystępowania łuszczycy i ŁZS jest ważne dla strategii terapeutycznej, jednak jest często opóźnione lub przeoczone [2]. W wyniku stosowania klasycznych metod leczenia często dochodzi do utraty skuteczności, wystąpienia działań niepożądanych lub niewystarczającego efektu terapii, dlatego też niezbędne jest poszukiwanie nowych metod terapeutycznych. Liczne badania wykazują, że sekukinumab w pełni ludzkie przeciwciało monoklonalne, które selektywnie neutralizuje interleukinę 17A (IL-17A), ma znaczącą skuteczność w leczeniu umiarkowanej do ciężkiej łuszczycy, ŁZS i zesztywniającego zapalenia stawów kręgosłupa, wykazując szybki początek działania i trwałe odpowiedzi o korzystnym profilu bezpieczeństwa.

\section{PATOGENEZA ŁUSZCZYCY I ZNACZENIE INTERLEUKINY I 7 (IL-I7) W ROZWOJU I PRZEBIEGU CHOROBY}

Obecny stan wiedzy na temat patogenezy łuszczycy sugeruje kluczową rolę osi IL-23/Th17/IL-17 w zapoczątkowaniu procesu zapalnego w łuszczycy, określanego jako „autozapalenie”. Oś Th1/IFN- $\gamma$ i cytokiny prozapalne (takie jak TNF) dominują jedynie w przewlekłej fazie choroby [3]. Identyfikacja komórek pomocniczych T-17 (Th17) w blaszkach łuszczycowych wskazywała na populację komórek $\mathrm{T}$ jako istotnego czynnika przyczyniającego się do prozapalnego stanu łuszczycy. W odpowiedzi na działanie kilku cytokin, m.in. IL-1 $\beta$, IL-6, transformującego czynnika wzrostu $\beta$ (transforming growth factor $\beta$ - TGF- $\beta$ ), komórki T CD4+ różnicują się w komórki Th17, których przeżycie i aktywacja są kontrolowane głównie przez IL-23. Po ekspozycji powstających komórek Th17 na IL-23 następuje zwiększenie produkcji innych cytokin efektorowych, $\mathrm{tj}$. IL-17A, IL-17F, IL-22 i czynnika martwicy nowotworów (TNF). Powstawanie IL-17 jest ściśle powiązane i zależne od obecności IL-23. Co ciekawe, IL-17 może być również wydzielana przez komórki tuczne, neutrofile, komórki T cytotoksyczne i komórki NK [4]. Rodzina cytokin IL-17 składa się z sześciu członków (IL-17A do IL-17F), z czego IL-17A jest pierwotną cytokiną efektorową linii komórkowej Th17. Cytokiny IL-17 pełnią swoje funkcje biologiczne poprzez wiązanie $z$ odpowiednim przezbłonowym receptorem (IL-17R), który jest heterodimerem złożonym z pięciu różnych podjednostek (IL-17RA-IL- 
subunits (IL-17RA-IL-17RE). IL-17A is approximately 10-30 times more potent than IL-17F in activating gene expression due to different ligand-receptor affinities. Some studies have shown that levels of IL17A, as well as of IL-17C and IL-17F, are significantly higher in psoriatic lesions than in healthy skin (an increase by 6.7, 4.1 and 8 times, respectively) [5]. Moreover, in psoriasis, IL-17 mRNA expression is higher in psioratic lesions compared to unchanged skin. It was also found that the level of IL-17A was significantly correlated with the severity of the disease [6]. IL-17A receptors are expressed on the surface of keratinocytes. Upon binding of IL-17A, numerous chemokines are produced that stimulate the secretion of chemoattractants for neutrophils (i.e., CXCL1, CXCL3, CXCL5, CXCL6, and CXCL8), leading to their accumulation in the epidermis and formation of Munro microabscesses. They also affect the recruitment of dendritic cells and T cells (CCL20). This complex interaction ultimately contributes to epidermal hyperproliferation and skin barrier dysfunction, important factors in the pathogenesis of psoriasis [3]. The action of IL-17A is potentiated by other inflammatory mediators, especially TNF, and their synergistic effect on keratinocytes maintains the positive feedback to increase the production of TNF and other mediators, and induces gene expression in keratinocytes. Due to the action of IL-17, there is also an increased expression of the intercellular adhesion-1 molecule on endothelial cells, which is involved in the migration of $\mathrm{T}$ cells to the focus of inflammation in the development of psoriatic lesions [7]. IL-17 plays an important role in many immune disorders, including psoriasis, rheumatoid arthritis, PsA, ankylosing spondylitis, uveitis, Crohn's disease, multiple sclerosis, and asthma. Moreover, IL-17A is also associated with the pathogenesis of some cancers, including $h u$ man cervical carcinoma, although the pro-inflammatory effect of IL-17A also appears to be a protective factor in some cancers [8] (fig. 1).

\section{THE ROLE OF ANTI-IL-I 7 IN THE TREATMENT OF PSORIASIS}

Currently, two monoclonal antibodies blocking IL-17 directly (ixekizumab and secukinumab) and a monoclonal antibody blocking the IL-17 receptor (brodalumab) have been authorized for the treatment of psoriasis in Europe. Effectiveness of the above-mentioned drugs has been confirmed in many multicentre clinical trials involving several thousand patients. The effectiveness of therapy with this group of drugs, expressed by the PASI75 ratio, is about $80-90 \%$. In addition, about $70 \%$ of patients achieves PASI90 improvement. Currently, drugs blocking
-17RE). IL-17A jest około 10-30 razy silniejsza niż IL-17F w aktywacji ekspresji genów, ze względu na różne powinowactwo ligand-receptor. Niektóre badania wykazały, że stężenia IL-17A oraz IL-17C i IL-17F są znamiennie wyższe w zmianach łuszczycowych niż w zdrowej skórze (wzrost odpowiednio o 6,7, 4,1 i 8 razy) [5]. Ponadto w łuszczycy ekspresja mRNA IL-17 jest wyższa w zmianach chorobowych w porównaniu ze skórą niezmienioną. Stwierdzono także, że poziom IL-17A jest istotnie skorelowany z ciężkością choroby [6]. Receptory IL-17A ulegają ekspresji na powierzchni keratynocytów. Po związaniu IL-17A dochodzi do wytwarzania licznych chemokin, które stymulują wydzielanie chemoatraktantów dla granulocytów obojętnochłonnych (tj. CXCL1, CXCL3, CXCL5, CXCL6 i CXCL8), co prowadzi do ich gromadzenia w naskórku i tworzenia mikroropni Munro. Wpływają także na rekrutację komórek dendrytycznych i komórek T (CCL20). Ta złożona interakcja ostatecznie przyczynia się do hiperproliferacji naskórka i dysfunkcji bariery skórnej, będących istotnymi czynnikami w patogenezie łuszczycy [3]. Działanie IL-17A jest wzmacniane przez inne mediatory zapalne, zwłaszcza TNF, a ich synergiczne działanie na keratynocyty utrzymuje dodatnie sprzężenie zwrotne w celu zwiększenia produkcji TNF i innych mediatorów, a także indukuje ekspresję genów w keratynocytach. Na skutek działania IL-17 dochodzi także do zwiększonej ekspresji cząsteczki adhezji międzykomórkowej 1 na komórkach śródbłonka, która bierze udział w rozwoju zmian łuszczycowych w migracji komórek T do ogniska zapalnego [7]. IL-17 odgrywa ważną rolę w wielu zaburzeniach immunologicznych, w tym łuszczycy, reumatoidalnym zapaleniu stawów, ŁZS, zesztywniającym zapaleniu stawów kręgosłupa, zapaleniu błony naczyniowej oka, chorobie Leśniowskiego-Crohna, stwardnieniu rozsianym i astmie. Co więcej, IL-17A ma także związek z patogenezą niektórych nowotworów, w tym human cervical carcinoma, chociaż prozapalne działanie IL-17A wydaje się również czynnikiem protekcyjnym w przypadku niektórych nowotworów [8] (ryc. 1).

\section{ROLA ANTY-IL- I 7 W LECZENIU ŁUSZCZYCY}

Obecnie do leczenia łuszczycy w Europie zostały zarejestrowane dwa przeciwciała monoklonalne blokujące bezpośrednio IL-17 (iksekizumab i sekukinumab) oraz przeciwciało monoklonalne blokujące receptor dla IL-17 (brodalumab). Skuteczność powyższych leków potwierdzono w wielu wieloośrodkowych badaniach klinicznych obejmujących kilka tysięcy pacjentów. Skuteczność terapii tą grupą leków wyrażona współczynnikiem PASI75 wynosi ok. $80-90 \%$. Ponadto około $70 \%$ chorych uzyskuje poprawę PASI90. Obecnie leki blokujące IL-17 stanowią obok inhibitorów IL-23 statystycznie najsku- 


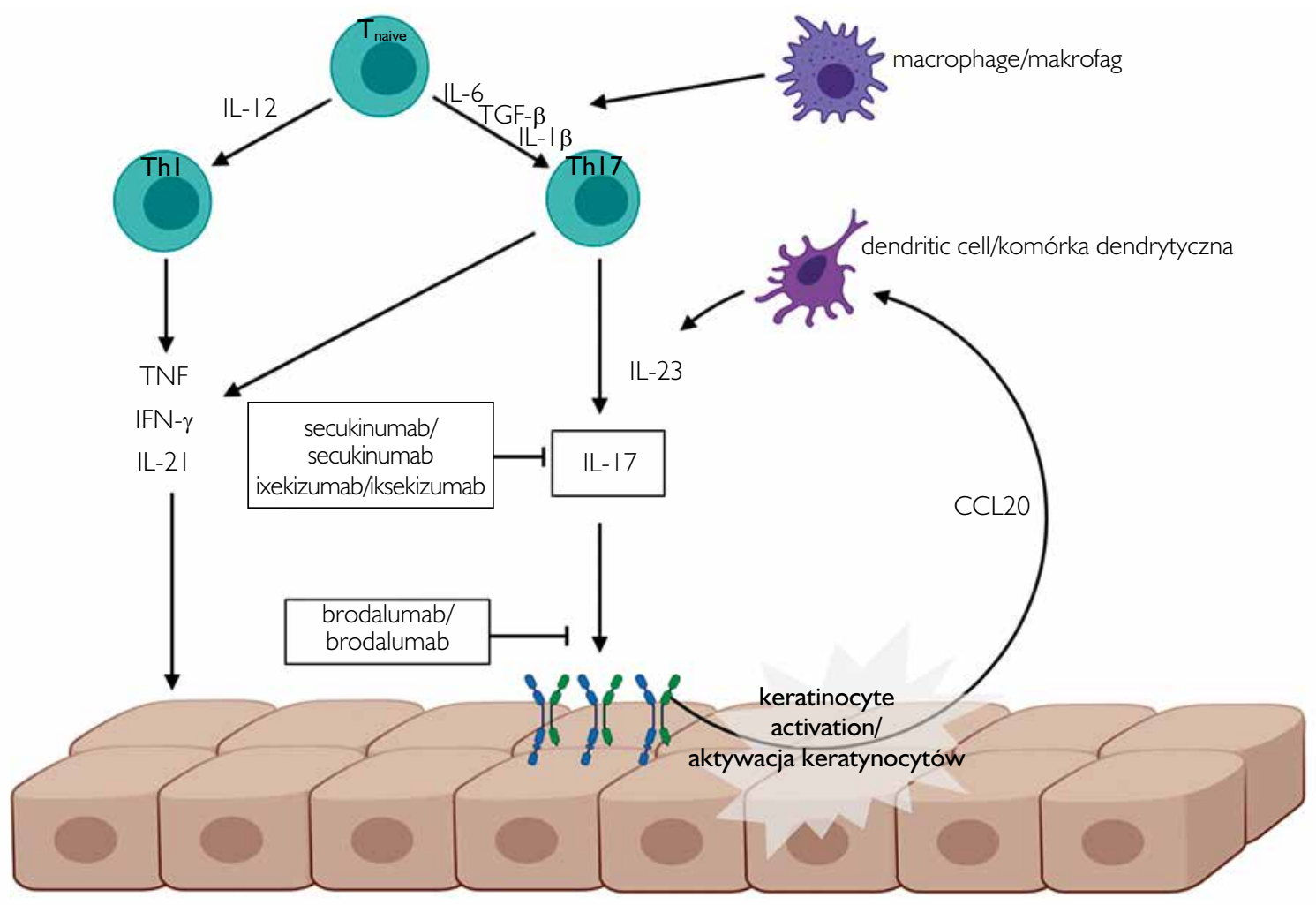

Figure I. The role of IL- I 7 in pathogenesis of psoriasis

Rycina I. Rola IL- I7 w patogenezie łuszczycy

IL-17 are statistically the most effective therapeutic option in the treatment of plaque psoriasis, along with IL-23 inhibitors.

\section{STRUCTURE OF SECUKINUMAB: CLINICAL TRIALS AND EFFECTIVENESS}

Secukinumab is a recombinant, fully human IgG1/ $\mathrm{k}$ monoclonal antibody that selectively binds to and neutralizes the pro-inflammatory cytokine IL-17A. It works by inhibiting the interaction of IL17A with the IL-17 receptor found on a variety of cell types, including keratinocytes [9]. This leads to inhibition of key pathways involved in the pathogenesis of psoriasis, while promoting the normalization of the immune and histological functions of the skin. Currently in Poland, secukinumab is approved for the treatment of plaque psoriasis, PsA and ankylosing spondylitis.

The safety profile of this group of drugs is very high, which has been confirmed in numerous clinical trials, including ERASURE, FIXTURE, FEATURE, JUNCTURE. Reich et al. conducted a safety analysis of 9 randomized, double-blind, phase 2 and 10 phase 3 clinical trials confirming the favorable long-term safety profile of secukinumab in patients with plaque psoriasis. The analysis included 4,674 patients who teczniejszą opcję terapeutyczną w leczeniu łuszczycy plackowatej.

\section{BUDOWA SEKUKINUMABU - BADANIA KLINICZNE I SKUTECZNOŚĆ}

Sekukinumab jest rekombinowanym, w pełni ludzkim przeciwciałem monoklonalnym klasy IgG1/к, które selektywnie wiąże się i neutralizuje prozapalną cytokinę, IL-17A. Jego działanie polega na hamowaniu interakcji IL-17A z receptorem dla IL-17, znajdującym się na różnych typach komórek, w tym keratynocytach [9]. Prowadzi to do zahamowania kluczowych szlaków biorących udział w patogenezie łuszczycy, jednocześnie promuje normalizację funkcji immunologicznych i histologicznych skóry. Aktualnie w Polsce sekukinumab jest zarejestrowany do leczenia łuszczycy plackowatej, ŁZS i zesztywniającego zapalenia stawów kręgosłupa.

Profil bezpieczeństwa tej grupy leków jest bardzo wysoki, co potwierdzono w licznych badaniach klinicznych, m.in. ERASURE, FIXTURE, FEATURE, JUNCTURE. Reich i wsp. dokonali analizy bezpieczeństwa 9 podwójnie zaślepionych badań klinicznych fazy 2 z randomizacją i 10 badań fazy 3, potwierdzając korzystny długoterminowy profil bezpieczeństwa sekukinumabu u pacjentów z łuszczycą plackowatą. Analizą objętych było 4674 pacjentów, którzy otrzyma- 
received any dose of secukinumab. The incidence of adverse events was similar for all 3 drug groups (secukinumab, etanercept and ustekinumab) but higher than placebo [9]. One of the common side effects of interest with IL-17 inhibitors is candidiasis of the skin and mucous membranes, which result from the mechanism of action of this class of drugs. Other side effects - although rare - are neutropenia and inflammatory bowel disease.

\section{WHAT DISTINGUISHES ANTI-IL-I 7 FROM OTHER BIOLOGICAL DRUGS}

\section{Speed of action}

The time it takes for patients to notice a clinically significant improvement is an important aspect of treatment. Insufficient speed of improvement may discourage patients from using the given treatment and have a negative impact on their quality of life. Papp et al. reviewed published efficacy data for adalimumab, infliximab, ustekinumab, etanercept, brodalumab, ixekizumab, and secukinumab to estimate the time needed to achieve a clinically meaningful effect, defined as the time $25 \%$ of patients achieve PASI75 or a decrease in mean baseline PASI by $50 \%$. The calculated times for $25 \%$ of patients to achieve PASI75 were 2.1 weeks (brodalumab), 2.4 weeks (ixekizumab), 3.0 weeks (high dose secukinumab), 3.5 weeks (infliximab), 4.6 weeks (adalimumab and ustekinumab high dose), 5.1 weeks (low dose ustekinumab), 6.6 weeks (high dose etanercept) and 9.5 weeks (low dose etanercept). The time to reach PASI50 was: 1.8 weeks (brodalumab), 1.9 weeks (ixekizumab), 3.0 weeks (high dose secukinumab), 3.5 weeks (adalimumab), 3.7 weeks (infliximab), 5.1 week (ustekinumab low dose), 6.5 weeks (etanercept high dose) and 10.9 weeks (etanercept low dose) for psoriasis [10]. The above results indicate a significantly faster action of drugs acting on the IL-17 pathway compared to other biological drugs studied.

\section{Selectivity}

Under physiological conditions, Th17 cells provide protection against extracellular bacterial and fungal pathogens such as Klebsiella pneumoniae, Citrobacter rodentium, Candida albicans and, to a lesser extent, Staphylococcus aureus. Although less directly, Th17 cells also play a role in protecting against intracellular bacteria such as Listeria monocytogenes, Salmonella enterica, and Mycobacterium tuberculosis [11]. A genetic deficiency in IL-17RA in humans has been shown to be associated with recurrent or persistent mucocutaneous infections caused by Candida albicans and Staphylococcus aureus infections [12]. IL-17A deficiency is also associated with chronic mucocutaneous candidiasis. Both IL-17A li jakąkolwiek dawkę sekukinumabu. Występowanie działań niepożądanych było podobne we wszystkich 3 grupach leków (sekukinumab, etanercept i ustekinumab), ale wyższe w porównaniu z placebo [9]. Jednym z częstych działań niepożądanych będących przedmiotem zainteresowania w przypadku inhibitorów IL-17 jest kandydoza skóry i błon śluzowych, które wynika z mechanizmu działania tej grupy leków. Inne skutki uboczne - choć rzadkie - to neutropenia i nieswoiste zapalenie jelit.

\section{CO WYRÓŻNIA ANTY-IL-I 7 NA TLE INNYCH LEKÓW BIOLOGICZNYCH}

\section{Szybkość działania}

Czas potrzebny pacjentom na zauważenie istotnej klinicznie poprawy jest ważnym aspektem leczenia. Niewystarczająca szybkość poprawy może zniechęcać pacjentów do stosowania danego leczenia oraz negatywnie wpływać na ich jakość życia. Papp i wsp. dokonali przeglądu opublikowanych danych dotyczących skuteczności adalimumabu, infliksymabu, ustekinumabu, etanerceptu, brodalumabu, iksekizumabu i sekukinumabu w celu oszacowania czasu niezbędnego do osiągnięcia klinicznie znaczącego efektu, zdefiniowanego jako czas, w którym 25\% pacjentów osiąga PASI75, lub zmniejszenie średniego wyjściowego PASI o 50\%. Obliczone czasy dla $25 \%$ pacjentów do osiągnięcia PASI75 wynosiły 2,1 tygodnia (brodalumab), 2,4 tygodnia (iksekizumab), 3 tygodnie (wysoka dawka sekukinumabu), 3,5 tygodnia (infliksymab), 4,6 tygodnia (adalimumab i ustekinumab w dużych dawkach), 5,1 tygodnia (ustekinumab w małych dawkach), 6,6 tygodnia (etanercept w dużych dawkach) i 9,5 tygodnia (etanercept w małych dawkach). Czas potrzebny do osiągnięcia PASI50 wynosił: 1,8 tygodnia (brodalumab), 1,9 tygodnia (iksekizumab), 3 tygodnie (wysoka dawka sekukinumabu), 3,5 tygodnia (adalimumab), 3,7 tygodnia (infliksymab), 5,1 tygodnia (ustekinumab w małej dawce), 6,5 tygodnia (etanercept w dużej dawce) i 10,9 tygodnia (etanercept w małej dawce) [10]. Powyższe wyniki wskazują na istotnie szybsze działanie leków działających na szlak IL-17 w porównaniu z pozostałymi badanymi lekami biologicznymi.

\section{Selektywność}

W warunkach fizjologicznych komórki Th17 chronią przed zewnątrzkomórkowymi patogenami bakteryjnymi i grzybiczymi, takimi jak Klebsiella pneumoniae, Citrobacter rodentium, Candida albicans oraz w mniejszym stopniu, Staphylococcus aureus. Chociaż mniej bezpośrednio, komórki Th17 odgrywają również rolę w ochronie przed bakteriami wewnątrzkomórkowymi, takimi jak Listeria monocytogenes, Salmonella enterica i Mycobacterium tuberculosis [11]. Wykazano, że niedobór genetyczny w IL-17RA u ludzi wiąże się z nawracającymi lub utrzymującymi 
and IL-17F are required for mucocutaneous immunity to Candida albicans, and blocking only one of these cytokines with secukinumab and ixekizumab may have a smaller impact on the risk of infection. At therapeutic doses used in psoriasis, secukinumab completely neutralizes IL-17A without neutralizing IL-17F. This specificity accounts for potentially fewer adverse effects compared to other currently available treatments. Expression of IL-17A, IL-17C, and IL-17F has been found to be elevated in psoriatic plaques, therefore targeting the receptor for all of these ligands and not only IL-17A may be more effective in controlling psoriasis, but may also be associated with increased risk of infection [13]. Brodalumab, which targets the IL-17 receptor subunit, IL-17RA, with potential for greater efficacy, may be associated with an increased risk of adverse effects [4].

\section{Low immunogenicity}

Biotherapeutic agents - including monoclonal antibodies (mAbs) - can be immunogenic, which can lead to formation of anti-drug antibodies, which can affect the pharmacokinetics of drugs, reducing their therapeutic effectiveness, or cause adverse effects, including hypersensitivity reactions. Reich et al. studied immunogenicity of secukinumab in patients treated for moderate to severe plaque psoriasis [14]. Of the 1,636 patients receiving secukinumab assessed for anti-drug antibodies, 32 developed anti-drug antibodies. As a result, less than $1 \%$ of patients develop antibodies to the drug annually. Presence of neutralizing antibodies was found in 9 out of 32 patients, but their development was not associated with loss of efficacy, safety, or pharmacokinetic changes of secukinumab. Moreover, in half of the cases, the antidrug antibodies presence was transient. Karle et al. assessed the immunogenic potential of secukinumab using two different in vitro assays: T-cell activation and peptide proteomics related to the major compositional histocompatibility complex (MAPP). In MAPP analyzes and $T$ cell activation assays, secukinumab showed a relatively small number of potential $\mathrm{T}$ cell epitopes and a correspondingly low percentage of $\mathrm{T}$ cell responses, comparable to other biotherapeutics with known low clinical immunogenicity. In contrast, biotherapeutics with an increased rate of clinical immunogenicity have demonstrated an increased number of potential $\mathrm{T}$ cell epitopes and increased rates of $\mathrm{T}$ cell responses in $\mathrm{T}$ cell activation assays [15]. The above results indicate an approximate correlation between results of the in vitro test and the occurrence of clinical immunogenicity. Clinical trials show that biotherapeutics used to treat psoriasis - such as adalimumab and infliximab - have higher immunogenicity compared to secukinumab. However, these indirect comparisons may not take into account differences się zakażeniami śluzówkowo-skórnymi spowodowanymi przez Candida albicans i zakażeniami Staphylococcus aureus [12]. Niedobór IL-17A jest także związany z przewlekłą kandydozą śluzówkowo-skórną. Zarówno IL-17A, jak i IL-17F są potrzebne do odporności śluzówkowo-skórnej w przypadku Candida albicans, a blokowanie tylko jednej z tych cytokin za pomocą sekukinumabu i iksekizumabu może mieć mniejszy wpływ na ryzyko zakażenia. W dawkach terapeutycznych stosowanych w łuszczycy sekukinumab całkowicie neutralizuje IL-17A bez neutralizowania IL-17F. Ta specyficzność odpowiada za potencjalnie mniejszą liczbę działań niepożądanych w porównaniu z innymi, obecnie dostępnymi terapiami. Stwierdzono, że ekspresja IL-17A, IL-17C i IL-17F jest podwyższona w blaszkach łuszczycowych, dlatego celowanie w receptor dla wszystkich tych ligandów i nie tylko IL-17A może być bardziej skuteczne w kontrolowaniu łuszczycy, ale może być również związane ze zwiększonym ryzykiem wystąpienia infekcji [13]. Brodalumab, który jest ukierunkowany na podjednostkę receptora IL-17 IL-17RA, mając potencjał lepszej skuteczności, może wiązać się ze zwiększonym ryzykiem wystąpienia działań niepożądanych [4].

\section{Niska immunogenność}

Bioterapeutyki - w tym przeciwciała monoklonalne (mAb) - mogą być immunogenne, co może prowadzić do powstawania przeciwciał przeciwlekowych. Te ostatnie mogą wpływać na farmakokinetykę leków, co powoduje obniżenie skuteczności terapeutycznej leku lub wystąpienie działań niepożądanych, w tym reakcji nadwrażliwości. Reich i wsp. przebadali immunogenność sekukinumabu u pacjentów leczonych z powodu umiarkowanej i ciężkiej łuszczycy plackowatej [14]. Spośród 1636 pacjentów otrzymujących sekukinumab, ocenianych pod kątem przeciwciał przeciwlekowych, u 32 osób wytworzyły się te przeciwciała. Wynika z tego, że u mniej niż 1\% pacjentów rocznie wytworzyły się przeciwciała przeciwko lekowi. U 9 spośród 32 pacjentów stwierdzono obecność przeciwciał neutralizujących, jednak ich powstanie nie wiązało się z utratą skuteczności, bezpieczeństwem lub zmianami farmakokinetycznymi sekukinumabu. Co więcej, w połowie przypadków obecność przeciwciał przeciwlekowych była przejściowa. Karle i wsp. ocenili potencjał immunogenny sekukinumabu, stosując dwa różne testy in vitro: aktywację komórek T i proteomikę peptydową związaną z głównym kompozycyjnym układem zgodności tkankowej (MAPP). W analizach MAPP i testach aktywacji komórek T sekukinumab wykazywał względnie małą liczbę potencjalnych epitopów komórek T i odpowiednio niski odsetek odpowiedzi komórek T, porównywalny z innymi bioterapeutykami o znanej niskiej klinicznej immunogenności. W przeciwieństwie do tego, bioterapeutyki o podwyższonym wskaźniku immunogenności klinicznej wykazały zwiększoną liczbę potencjalnych epitopów 
in immunogenicity timeframes, differences between designs of clinical trials, and differences in anti-drug antibodies testing, including sampling time points, detection and reporting methodologies, and therefore requires further investigation.

\section{Safety in tuberculosis}

By blocking mediators of innate and adaptive immunity, biotherapeutics may carry a risk of increased opportunistic infections. In patients with psoriasis, a dose-dependent but overall low incidence of transient mild to moderate mucosal and skin candidiasis that was well controlled with standard therapy was observed during 52 weeks of treatment with secukinumab [16]. In pooled data from five randomized, double-blind, placebo-controlled, phase 3 clinical trials of secukinumab safety in patients with moderate to severe plaque psoriasis, no cases of latent tuberculosis reactivation were observed after one year. It seems that IL-17A producing $\gamma \delta T$ cells and CD4 + T cells may play a protective or pathological role during various phases of Mycobacterium tuberculosis infection [17]. Fowler et al. also assessed the incidence of tuberculosis reactivation in patients treated with anti-IL-17, not finding any cases of tuberculosis reactivation in patients treated with IL-17 inhibitors [18]. In an in vitro study, the effects of antiTNF (adalimumab) and secukinumab on dormant Mycobacterium tuberculosis $\mathrm{H} 37 \mathrm{Rv}$ were investigated in a new human 3D model of microgranuloma, auramine-O, Nile red staining, and Mycobacterium tuberculosis resistance to rifampicin were measured. In vitro anti-TNF treatment showed increased auramine-O staining, decreased Nile red, and decreased resistance to rifampicin, indicative of mycobacterial reactivation. In contrast, treatment with secukinumab was comparable to the control, indicating no effect on latent Mycobacterium tuberculosis [17]. Cytokines, and in particular tumor necrosis factor, are critical in combating Mycobacterium tuberculosis infections. It is therefore not surprising that anti-TNF therapy is one of the major risk factors for reactivating latent Mycobacterium tuberculosis infection. Therefore, in patients with suspected latent tuberculosis infection or with a history of tuberculosis, anti-TNF should not be used. To date, clinical and preclinical studies with secukinumab have shown no evidence of reactivation of latent tuberculosis [19]. On their basis, it seems that IL-17 inhibitors can be safely used in psoriasis patients with latent tuberculosis infection who receive chemoprophylaxis.

\section{Effect on body weight}

In the case of systemic treatment of psoriasis, an inferior efficacy and a higher incidence of side effects are often observed in obese patients compared to patients whose body weight was normal. A prime example is komórek T i zwiększone wskaźniki odpowiedzi komórek T w testach aktywacji komórek T [15]. Powyższe wyniki wskazują na przybliżoną korelację między wynikami testu in vitro a występowaniem klinicznej immunogenności. Badania kliniczne dowodzą, że bioterapeutyki stosowane w leczeniu łuszczycy, takie jak adalimumab i infliksymab, mają wyższą immunogenność w porównaniu z sekukinumabem. Jednak takie pośrednie porównania mogą nie uwzględniać różnic w ramach czasowych, w których obserwuje się immunogenność, różnic między badaniami klinicznymi oraz różnic $w$ testach przeciwciał przeciwlekowych, w tym punktów czasowych pobierania próbek, metodologii wykrywania i raportowania, dlatego zagadnienie to wymaga dalszych badań.

\section{Bezpieczeństwo w gruźlicy}

Poprzez blokowanie mediatorów odporności wrodzonej i adaptacyjnej bioterapeutyki mogą powodować zwiększone ryzyko wystąpienia zakażeń oportunistycznych. U pacjentów z łuszczycą podczas 52-tygodniowej terapii sekukinumabem zaobserwowano zależną od dawki, ale ogólnie niewielką częstość występowania przejściowej, łagodnej do umiarkowanej kandydozy błon śluzowych i skóry, która była dobrze kontrolowana za pomocą standardowej terapii [16]. W zbiorczych danych z 5 podwójnie zaślepionych, kontrolowanych placebo badań klinicznych III fazy z randomizacją, dotyczących bezpieczeństwa stosowania sekukinumabu u pacjentów z umiarkowaną do ciężkiej łuszczycą plackowatą po roku nie zaobserwowano żadnych przypadków reaktywacji utajonej gruźlicy. Wydaje się, że komórki үठT produkujące IL-17A i limfocyty T CD4+ mogą odgrywać rolę ochronną lub patologiczną podczas różnych faz zakażenia Mycobacterium tuberculosis [17]. Także Fowler i wsp. ocenili częstość reaktywacji gruźlicy u pacjentów leczonych anty-IL-17, nie stwierdzając przypadków reaktywacji gruźlicy u pacjentów leczonych inhibitorami IL-17 [18]. W badaniu in vitro zbadano wpływ anty-TNF (adalimumab) i sekukinumabu na uśpione Mycobacterium tuberculosis $\mathrm{H} 37 \mathrm{Rv}$ w nowym ludzkim trójwymiarowym modelu mikroziarniniaka, mierzono auraminę-O, wybarwianie czerwienią Nilu i odporność Mycobacterium tuberculosis na ryfampicynę. W warunkach in vitro leczenie anty-TNF wykazało zwiększone wybarwienie dla auraminy-O, zmniejszone czerwienią Nilu i zmniejszoną oporność na ryfampicynę, co wskazuje na reaktywację prątków. Przeciwnie, leczenie sekukinumabem było porównywalne z kontrolą, co wskazuje na brak wpływu na utajoną postać Mycobacterium tuberculosis [17]. Cytokiny, zwłaszcza czynnik martwicy nowotworów, mają kluczowe znaczenie w zwalczaniu zakażeń Mycobacterium tuberculosis. Nie dziwi fakt, że terapia lekami anty-TNF stanowi jeden z głównych czynników ryzyka reaktywacji utajonej infekcji Mycobacterium tuberculosis. W związku z powyższym w przypadku pacjentów z podejrzeniem utajonego zakażenia gruźlicą lub też z przebytą gruźlicą 
methotrexate, which carries a greater risk of hepatic steatosis and liver fibrosis in obese patients [20]. Obese patients require higher doses of acitretin and cyclosporine, leading to an increased risk of side effects [21]. Also, clinical trials on anti-TNF or monoclonal antibodies against IL-12 and IL-23 (ustekinumab) indicate better effectiveness of therapy in patients with normal body mass index (BMI), compared to patients with increased BMI. Moreover, weight gain was observed in patients during anti-TNF therapy. In the case of antiIL-17, effectiveness of the therapy is good regardless of body weight. In the pooled analysis of the Phase 3 studies, ERASURE and FIXTURE, response to treatment was analyzed by body weight quartiles (42-69.9, 70-82, 82.1-97, and 97.1-219.1 kg). Although responses remained clinically significant across all weight groups, there was a trend towards a poorer response with increasing body weight. In addition, data from the Phase 3 CLEAR study showed that secukinumab $300 \mathrm{mg}$ was clinically and statistically significantly more effective (PASI90 at week 16) than ustekinumab $90 \mathrm{mg}$ in patients weighing more than $100 \mathrm{~kg}$ [22]. Unlike anti-TNF, IL-17 inhibitors have not been observed to cause weight gain in clinical trials [21, 23].

\section{Effect on cardiovascular diseases}

Psoriasis is now considered a systemic disease associated with inflammatory and metabolic diseases and associated with an increased risk of cardiovascular diseases. Secukinumab is highly effective in psoriasis, but its effect on markers of cardiovascular disease is unknown. Results of the CARIMA study assessing markers of cardiovascular risk in secukinumab-treated patients with moderate to severe plaque psoriasis without clinical signs of cardiovascular disease have been promising. The main endpoint was the assessment of endothelial function measured by the method of determining the degree of dilatation of the brachial artery after previous occlusion of arteries of the forearm or of the proximal part (flow-mediated dilatation - FMD). Baseline FMD was significantly lower in psoriasis patients than in healthy volunteers. At 52 weeks of therapy, FMD values were significantly higher than baseline in patients receiving $300 \mathrm{mg}$ secukinumab for 52 weeks [7]. The CARIMA study showed that secukinumab may have a beneficial effect on cardiovascular risk by improving endothelial function in patients with plaque psoriasis. The effect of secukinumab on various cardiometabolic parameters was also examined in a pooled analysis of three phase 3 studies: FIXTURE, ERASURE and SCULPTURE. Various cardiometabolic parameters including fasting plasma glucose, uric acid and C-reactive protein (CRP) were assessed for 52 weeks in patients with moderate to severe psoriasis. Stable fasting plasma glucose levels were observed for both nie powinno się stosować anty-TNF. Dotychczas badania kliniczne i przedkliniczne $\mathrm{z}$ użyciem sekukinumabu nie wykazały dowodów na reaktywację utajonej gruźlicy [19]. Na ich podstawie wydaje się, że inhibitory IL-17 mogą być bezpiecznie stosowane u pacjentów z łuszczycą z latentnym zakażeniem grużlicą, którzy otrzymują chemoprofilaktykę

\section{Wpływ na masę ciała}

W przypadku leczenia ogólnego łuszczycy często obserwuje się gorszą skuteczność i większą częstość występowania działań niepożądanych u osób otyłych w porównaniu z pacjentami o prawidłowej masie ciała. Doskonałym przykładem jest metotreksat, powodujący większe ryzyko stłuszczenia wątroby i zwłóknienia wątroby u otyłych pacjentów [20]. Pacjenci otyli wymagają większych dawek acytretyny i cyklosporyny, co prowadzi do zwiększonego ryzyka wystąpienia działań niepożądanych [21]. Badania kliniczne dotyczące anty-TNF lub monoklonalnego przeciwciała przeciwko IL-12 i IL-23 (ustekinumab) wskazują na lepszą skuteczność terapii u pacjentów z prawidłowym wskaźnikiem masy ciała (body mass index - BMI) w porównaniu z pacjentami z podwyższonym BMI. W trakcie terapii anty-TNF u pacjentów obserwowano przyrost masy ciała. W przypadku anty-IL-17 stwierdza się dobrą skuteczność terapii, niezależnie od masy ciała. W zbiorczej analizie badań III fazy, ERASURE i FIXTURE, odpowiedź na leczenie analizowano według kwartyli masy ciała (42-69,9, 70-82, 82,1-97 i 97,1-219,1 kg). Mimo że odpowiedzi pozostawały klinicznie znaczące we wszystkich grupach wagowych, występowała tendencja do słabszej odpowiedzi wraz ze wzrostem masy. Ponadto dane $z$ badania fazy III CLEAR wykazały, że sekukinumab w dawce $300 \mathrm{mg}$ miał statystycznie istotnie wyższą skuteczność (PASI90 w 16. tygodniu) niż ustekinumab w dawce $90 \mathrm{mg}$ u pacjentów o masie ciała powyżej 100 kg [22]. Inaczej niż w przypadku anty-TNF, w badaniach klinicznych nie obserwowano, aby inhibitory IL-17 powodowały przyrost masy ciała [21, 23].

\section{Wpływ na choroby układu sercowo- -naczyniowego}

Łuszczyca jest obecnie uważana za chorobę ogólnoustrojową współistniejącą z chorobami zapalnymi, metabolicznymi oraz związaną ze zwiększonym ryzykiem wystąpienia chorób sercowo-naczyniowych. Sekukinumab cechuje się znaczną skutecznością w łuszczycy, ale wpływ na markery chorób sercowo-naczyniowych jest nieznany. Obiecujące okazały się wyniki badania CARIMA, w którym oceniano markery ryzyka sercowo-naczyniowego u pacjentów leczonych sekukinumabem z łuszczycą plackowatą o nasileniu umiarkowanym do ciężkiego, bez klinicznych objawów choroby sercowo-naczyniowej. Głównym punktem końcowym była 
secukinumab and etanercept between baseline and week 52. Interestingly, in patients with elevated fasting plasma glucose at baseline, secukinumab treatment was associated with a reduction in FPG levels at week 52 (reduction from $173.8 \mathrm{mg} / \mathrm{dl}$ to $160.7 \mathrm{mg}$ / dl). A similar trend was observed for etanercept (reduction from $178.3 \mathrm{mg} / \mathrm{dl}$ to $162.9 \mathrm{mg} / \mathrm{dl}$ ). Studies have shown that both secukinumab and etanercept have a neutral effect on uric acid levels at normal baseline values, while both treatments were associated with decreased uric acid levels in patients with elevated baseline uric acid levels. CRP levels in patients treated with secukinumab and etanercept decreased rapidly and remained low (from $6.2 \mathrm{mg} / 1$ to $3.8 \mathrm{mg} / 1$ for secukinumab and from $5.2 \mathrm{mg} / 1$ to $2.7 \mathrm{mg} / 1$ for etanercept) [23]. These analyzes suggest neutral or even favorable long-term trends in cardiometabolic parameters during secukinumab treatment.

\section{Inflammatory bowel diseases and plaque psoriasis}

The estimated incidence of psoriasis in patients with Crohn's disease is $9.6 \%$ (compared to $2.2 \%$ in the general population), while the incidence of Crohn's disease is estimated at $0.5 \%$ in patients with psoriasis (compared to $0.2 \%$ in the general population). Similar trends are seen in ulcerative colitis [24, 25]. For psoriasis and inflammatory bowel disease (IBD), some overlapping immunological and genetic features have been described. Genetic polymorphisms at the interleukin 23 receptor (IL-23R) that alter IL-12/23 signaling are found in both psoriasis and IBD. Therefore, some drugs can be used to treat both psoriasis and IBD. These drugs include infliximab and adalimumab (ulcerative colitis, Crohn's disease), and ustekinumab (Crohn's disease). However, be aware that some treatments for psoriasis have the potential to worsen or trigger IBD. In the referred clinical trials, biological drugs such as etanercept, secukinumab, brodalumab and ixekizumab have shown efficacy in psoriasis and PsA, but there was a risk that they may exacerbate or induce IBD [26]. Although a direct causal relationship has not been established and the risk of an IBD exacerbation or induction is low [27], appropriate screening and caution is recommended when considering IL-17 inhibitor therapy in patients with a history of IBD. In patients with a definitive diagnosis of IBD, alternative treatment options should be considered.

\section{Effect on the course of COVID-19}

The COVID-19 pandemic has raised much concern among psoriasis patients and their dermatologists about the risks associated with continuation of biological therapies. Most experts recommend continuing treatment of psoriasis with biologics, although ocena funkcji śródbłonka mierzona za pomocą metody określającej stopień rozszerzenia tętnicy ramiennej po wcześniejszej okluzji tętnic przedramienia lub proksymalnej części (flow-mediated dilatation - FMD). Wyjściowa FMD była istotnie mniejsza u pacjentów z łuszczycą niż u zdrowych ochotników. W 52. tygodniu terapii wartości FMD były znamiennie wyższe niż wyjściowe wartości u pacjentów otrzymujących dawkę $300 \mathrm{mg}$ sekukinumabu przez 52 tygodnie [7]. Badanie CARIMA wykazało, że sekukinumab może korzystnie wpływać na ryzyko sercowo-naczyniowe poprzez poprawę funkcji śródbłonka pacjentów z łuszczycą plackowatą. Wpływ sekukinumabu na różne parametry kardiometaboliczne zbadano także w zbiorczej analizie trzech badań III fazy: FIXTURE, ERASURE i SCULPTURE. U pacjentów z łuszczycą o nasileniu od umiarkowanego do ciężkiego przez 52 tygodnie oceniono różne parametry kardiometaboliczne, w tym stężenie glukozy w osoczu na czczo, kwas moczowy i białko C-reaktywne (C-reactive protein - CRP). Zarówno dla sekukinumabu, jak i etanerceptu obserwowano stabilne stężenia glukozy w osoczu na czczo między początkiem przyjmowania leków a 52. tygodniem. Co ciekawe, u pacjentów z wyjściowo podwyższonym stężeniem glukozy w osoczu na czczo leczenie sekukinumabem wiązało się ze zmniejszeniem stężenia glukozy w osoczu na czczo w 52. tygodniu (redukcja z 173,8 mg/dl do 160,7 mg/ dl). Podobną tendencję zaobserwowano dla etanerceptu (redukcja z 178,3 mg/dl do 162,9 mg/dl). Badania wykazały, że zarówno sekukinumab, jak i etanercept mają neutralny wpływ na stężenie kwasu moczowego w przypadku prawidłowych wyjściowych wartości badania, podczas gdy obie terapie wiązały się z redukcją stężenia kwasu moczowego u pacjentów z podwyższonym wyjściowym stężeniem kwasu moczowego. Poziomy CRP u pacjentów leczonych sekukinumabem i etanerceptem obniżały się szybko i utrzymywały się na niskim poziomie (z 6,2 mg/1 do 3,8 $\mathrm{mg} / 1 \mathrm{w}$ przypadku sekukinumabu i z 5,2 mg/1 do 2,7 mg/l dla etanerceptu) [23]. Analizy te sugerują neutralne lub nawet korzystne długoterminowe tendencje zmiany parametrów kardiometabolicznych podczas leczenia sekukinumabem.

\section{Choroby zapalne jelit a łuszczyca plackowata}

Szacuje się, że częstość występowania łuszczycy u pacjentów z chorobą Leśniowskiego-Crohna wynosi 9,6\% (w porównaniu z 2,2\% w populacji ogólnej), podczas gdy choroba Leśniowskiego-Crohna występuje u 0,5\% pacjentów z łuszczycą (w porównaniu z 0,2\% w populacji ogólnej). Podobne tendencje występują w przypadku wrzodziejącego zapalenia jelita grubego $[24,25]$. Opisano nakładające się cechy immunologiczne i genetyczne w przypadku łuszczycy i nieswoistych zapaleń jelit (inflammatory bowel diseases - IBD). Polimorfizmy genetyczne w receptorze dla interleukiny 23 (IL-23R), które zmieniają sygnalizację w szlaku 
temporary suspension of the treatment should be considered in the event of development of COVID-19 symptoms. Due to the current epidemiological situation, the impact of chronic therapies on the course of COVID-19 seems to be of key importance. Fuogerousse et al. assessed the incidence of severe COVID-19 infections, defined as hospitalization or death, in patients with psoriasis receiving biological therapy and conventional treatment. Of the 1,418 patients studied, 300 received metotrexate (MTX), 26 cyclosporine (CsA), 4 acitretin, 48 apremilast, 25 etanercept, 165 adalimumab, 40 infliximab, 8 certolizumab pegol, 240 ustekinumab, 206 secukinumab, 112 ixekizumab, 38 brodalumab, 146 guselcumab, 25 risankizumab, and 35 MTX combined with a biological drug. Overall, $22.4 \%$ of patients receiving systemic therapy and $13.8 \%$ of those taking biologics discontinued treatment during the pandemic. COVID-19 infection was confirmed by polymerase chain reaction (PCR) in 12 patients, 5 of which required hospitalization (coexistence of psoriasis with other diseases), no deaths were reported [28]. The above study suggests that there is no increased incidence of severe COVID-19 in patients with psoriasis treated systemically. Many other preliminary reports from patients with COVID-19 who were treated with secukinumab also suggest a favorable course of infections [29-32] with the exception of one 74-year-old male patient with multiple diseases requiring mechanical ventilation [33].

Current knowledge confirms the important role of release of several cytokines in COVID-19, including IL-17, especially in patients with pneumonia [34]. These reports suggest that, contrary to initial concerns, anti-IL-17 treatment may provide additional benefits rather than being dangerous [35]. For SARSCoV-2, the severity of the disease positively correlates with the levels of IL-17 and other T 17-associated pro-inflammatory cytokines such as IL-1, IL-6, IL-15, TNF, and IFN- $\gamma$. In acute lung injury (ALI) and acute respiratory distress syndrome (ARDS), similarly as in psoriasis, the balance of pro-inflammatory and antiinflammatory cytokines is disturbed. Increased production of pro-inflammatory cytokines in lungs leads to diffuse alveolar damage. In the course of ARDS, IL-17 enhances destruction of pulmonary parenchyma by abnormal neutrophil recruitment, stimulating the production of proinflammatory mediators and preventing apoptosis due to induction of expression of the granulocyte colony stimulating factor. It is also known that IL-17 stimulates production of IL-1 and IL-6 and reduces neutrophil recruitment. Therefore, it seems likely that the use of IL-17 inhibitors could inhibit several pathways involved in ARDS, resulting in a more favorable course of the disease [36].
IL-12/23, występują zarówno w łuszczycy, jak i w IBD. W związku z powyższym część leków można stosować do leczenia zarówno łuszczycy, jak i IBD. Do leków tych należą infliksymab, adalimumab (wrzodziejące zapalenie jelita grubego, choroba Leśniowskiego-Crohna) oraz ustekinumab (choroba Leśniowskiego-Crohna). Należy jednak pamiętać, że niektóre metody leczenia łuszczycy mogą potencjalnie pogorszyć lub wywołać IBD. W opisywanych badaniach klinicznych leki biologiczne, takie jak etanercept, sekukinumab, brodalumab i iksekizumab, cechowały się skutecznością w łuszczycy i ŁZS, natomiast wiążą się z ryzykiem wywoływania lub zaostrzania IBD [26]. Mimo że nie ustalono bezpośredniego związku przyczynowego, a ryzyko zaostrzenia lub wywołania IBD jest niewielkie [27], zaleca się przeprowadzenie odpowiednich badań przesiewowych i ostrożność przy rozważaniu terapii inhibitorami IL-17 u pacjentów z IBD $\mathrm{w}$ wywiadzie. U chorych z ostatecznym rozpoznaniem IBD należy rozważyć inne opcje leczenia.

\section{Wpływ na przebieg COVID-19}

Pandemia COVID-19 wzbudziła wiele obaw wśród pacjentów z łuszczycą i ich dermatologów co do ryzyka wynikającego z kontynuacji terapii biologicznych. Większość ekspertów rekomenduje kontynuowanie leczenia łuszczycy lekami biologicznymi, chociaż w przypadku wystąpienia objawów COVID-19 należy rozważyć czasowe zawieszenie terapii. W związku z aktualnym stanem epidemiologicznym kluczowy wydaje się wpływ terapii przewlekłych na przebieg COVID-19. Fuogerousse i wsp. oceniali częstość występowania ciężkich zakażeń COVID-19, definiowanych jako hospitalizacja lub zgon u pacjentów z łuszczycą otrzymujących terapię biologiczną i leczenie klasyczne [28]. Spośród 1418 badanych pacjentów 300 otrzymywało metotreksat (MTX), 26 cyklosporynę (CsA), 4 acytretynę, 48 apremilast, 25 etanercept, 165 adalimumab, 40 infliksymab, 8 certolizumab pegol, 240 ustekinumab, 206 sekukinumab, 112 iksekizumab, 38 brodalumab, 146 guselkumab, 25 ryzankizumab i 35 leczenie skojarzone MTX i leku biologicznego. 22,4\% pacjentów leczonych ogólnie i $13,8 \%$ przyjmujących leki biologiczne przerwało leczenie w czasie pandemii. Infekcja COVID-19 została potwierdzona badaniem reakcji łańcuchowej polimerazy (PCR) u 12 pacjentów, w tym 5 wymagało hospitalizacji (współistnienie łuszczycy z innymi schorzeniami), nie stwierdzono zgonów. Powyższe badanie sugeruje, że nie ma zwiększonej częstości występowania ciężkiego COVID-19 u pacjentów z łuszczycą leczonych ogólnie. Wiele innych wstępnych doniesień dotyczących pacjentów z COVID-19, którzy byli leczeni sekukinumabem, również sugeruje korzystny przebieg [29-32] infekcji z wyjątkiem 


\section{CONCLUSIONS}

Psoriasis is one of the few non-communicable diseases that the World Health Organization has identified as a major global health problem. This is due to, inter alia, its chronic course, stigmatization encountered by affected patients, and links with many other serious diseases, such as hypertension, myocardial infarction or diabetes [37]. Over the past decade, targeted therapies have significantly improved the treatment of plaque psoriasis, and with the advent of drugs that affect the IL-17/IL-23 pathway, "clean skin" has become a viable treatment target. Characterized by high effectiveness and safety of the therapy these drugs are a very good alternative to older biotherapeutics.

\section{CONFLICT OF INTEREST}

The authors declare no conflict of interest. jednego 74-letniego mężczyzny z wieloma chorobami towarzyszącymi, wymagającego tlenoterapii [33].

Obecna wiedza potwierdza istotną rolę uwalniania kilku cytokin w COVID-19, w tym IL-17, zwłaszcza $\mathrm{u}$ pacjentów z zapaleniem płuc [34]. Doniesienia te sugerują, że wbrew początkowym obawom leczenie anty-IL-17 może przynieść dodatkowe korzyści, a nie być niebezpieczne [35]. W przypadku SARS-CoV-2 ciężkość choroby dodatnio koreluje ze stężeniami IL-17 i innych cytokin prozapalnych związanych z komórkami Th-17, takich jak IL-1, IL-6, IL-15, TNF i IFN-ץ. W ostrym uszkodzeniu płuc (acute lung injury - ALI) i zespole ostrej niewydolności oddechowej (acute respiratory distress syndrome - ARDS), podobnie jak w łuszczycy, dochodzi do zaburzenia równowagi cytokin prozapalnych i przeciwzapalnych. Wzmożona produkcja cytokin prozapalnych w płucach prowadzi do rozlanego uszkodzenia pęcherzyków płucnych. W przebiegu ARDS IL-17 nasila destrukcję miąższu płuc poprzez nieprawidłową rekrutację neutrofilów, stymulację produkcji mediatorów prozapalnych i zapobiega apoptozie $\mathrm{w}$ wyniku indukcji ekspresji czynnika stymulującego tworzenie kolonii granulocytów. Wiadomo także, że IL-17 pobudza wytwarzanie IL-1 i IL-6 oraz skutkuje zmniejszeniem rekrutacji neutrofilów. W związku z powyższym prawdopodobne wydaje się, że zastosowanie inhibitorów IL-17 mogłoby zahamować kilka szlaków odgrywających rolę w ARDS, co wpłynęłoby na korzystniejszy przebieg choroby [36].

\section{PODSUMOWANIE}

Łuszczyca jest jedną z nielicznych chorób niezakaźnych, które Światowa Organizacja Zdrowia uznała za główny globalny problem zdrowotny. Wynika to między innymi z jej przewlekłego przebiegu, stygmatyzacji, z jaką na co dzień spotykają się pacjenci, i powiązania $z$ wieloma innymi poważnymi chorobami, takimi jak nadciśnienie, zawał serca i cukrzyca [37]. W czasie ostatniej dekady terapie celowane znacznie poprawiły skuteczność leczenia łuszczycy plackowatej, a wraz z pojawieniem się leków oddziałujących na szlak IL-17/IL-23 brak zmian skórnych stał się realnym celem leczenia. Leki te stanowią bardzo dobrą inną możliwość terapeutyczną w stosunku do starszych bioterapeutyków, gdyż charakteryzują się wysoką skutecznością i bezpieczeństwem terapii.

\section{KONFLIKT INTERESÓW}

Autorzy nie zgłaszają konfliktu interesów. 


\section{References}

\section{Piśmiennictwo}

1. Borzęcki A., Koncewicz A., Raszewska-Famielec M., Dudra-Jastrzębska M.: Epidemiology of psoriasis in the years 20082015 in Poland. Dermatol Rev 2018, 105, 693-700.

2. Reich K., Krüger K., Mössner R., Augustin M.: Epidemiology and clinical pattern of psoriatic arthritis in Germany: a prospective interdisciplinary epidemiological study of 1511 patients with plaque-type psoriasis. Br J Dermatol 2009, 160, 1040-7.

3. Owczarczyk-Saczonek A., Placek W.: Interleukin-17 as a factor linking the pathogenesis of psoriasis with metabolic disorders. Int J Dermatol 2017, 56, 260-8.

4. Lønnberg A.S., Zachariae C., Skov L.: Targeting of interleukin-17 in the treatment of psoriasis. Clin Cosmetic Investig Dermatol 2014, 7, 251-9.

5. Johansen C., Usher P.A., Kjellerup R.B., Lundsgaard D., Iversen L., Kragballe K.: Characterization of the interleukin-17 isoforms and receptors in lesional psoriatic skin. Br J Dermatol 2009, 160, 319-324.

6. Martin D.A., Towne J.E., Kricorian G., Klekotka P., Gudjonsson J.E., Krueger J.G., et al.: The emerging role of IL-17 in the pathogenesis of psoriasis: preclinical and clinical findings. J Investig Dermatol 2013, 133, 17-26.

7. von Stebut E., Reich K., Thaçi D., Koenig W., Pinter A., Korber A., et al.: Impact of secukinumab on endothelial dysfunction and other cardiovascular disease parameters in psoriasis patients over 52 weeks. J Investig Dermatol 2019, 139, 1054-1062.

8. Yang B., Kang H., Fung A., Zhao H., Wang T., Ma D.: The role of interleukin 17 in tumour proliferation, angiogenesis, and metastasis. Mediators Inflamm 2014, 2014, 623759.

9. Reich K., Warren R.B., Coates L.C., Di Comite G.: Long-term efficacy and safety of secukinumab in the treatment of the multiple manifestations of psoriatic disease. J Eur Acad Dermatol Venereol 2020, 34, 1161-1173.

10. Papp K.A., Lebwohl M.G.: Onset of action of biologics in patients with moderate-to-severe psoriasis. J Drugs Dermatol 2017, $17,247-250$

11. Curtis M.M., Way S.S.: Interleukin-17 in host defence against bacterial, mycobacterial and fungal pathogens. Immunology 2009, 126, 177-185.

12. Lévy R., Okada S., Béziat V., Moriya K., Liu C., Chai L.Y.A., et al.: Genetic, immunological, and clinical features of patients with bacterial and fungal infections due to inherited IL-17RA deficiency. Proc Natl Acad Sci USA 2016, 113, E8277-E8285.

13. Frieder J., Kivelevitch D., Menter A.: Secukinumab: a review of the anti-IL-17A biologic for the treatment of psoriasis. Ther Adv Chronic Dis 2018, 9, 5-21.

14. Reich K., Blauvelt A., Armstrong A., Langley R.G., de Vera A., Kolbinger F., et al.: Secukinumab, a fully human anti-interleukin-17A monoclonal antibody, exhibits low immunogenicity in psoriasis patients treated up to 5 years. J Eur Acad Dermatol Venereol 2019, 33, 1733-1741.

15. Karle A., Spindeldreher S., Kolbinger F.: Secukinumab, a novel anti-IL-17A antibody, shows low immunogenicity potential in human in vitro assays comparable to other marketed biotherapeutics with low clinical immunogenicity. mAbs 2016, 8, 536-550.

16. Van De Kerkhof P.C.M., Griffiths C.E.M., Reich K., Leonardi C.L., Blauvelt A., Tsai TF., et al.: Secukinumab long-term safety experience: a pooled analysis of 10 phase II and III clinical studies in patients with moderate to severe plaque psoriasis. J Am Acad Dermatol 2016, 75, 83-98.

17. Kammüller M., Tsai T.F., Griffiths C.E.M., Kapoor N., Kolattukudy P.E., Brees D., et al.: Inhibition of IL-17A by secukinumab shows no evidence of increased Mycobacterium tuberculosis infections. Clin Transl Immunol 2017, 6, e152.

18. Fowler E., Ghamrawi R.I., Ghiam N., Liao W., Wu J.J.: Risk of tuberculosis reactivation during interleukin-17 inhibitor therapy for psoriasis: a systematic review. J Eur Acad Dermatol Venereol 2020, 34, 1449-1456.

19. Harris J., Keane J.: How tumour necrosis factor blockers interfere with tuberculosis immunity. Clin Exp Immunol 2010, 161, $1-9$

20. Rosenberg P., Urwitz H., Johannesson A., et al.: Psoriasis patients with diabetes type 2 are at high risk of developing liver fibrosis during methotrexate treatment. J Hepatol 2007, 46, 1111-1118.

21. Kaushik S.B., Lebwohl M.G.: Psoriasis: which therapy for which patient: psoriasis comorbidities and preferred systemic agents. J Am Acad Dermatol 2019, 80, P27-P40.

22. Tiberio R., Graziola F., Miglino B., Veronese F., Annali G., Savoia P.: Secukinumab for psoriasis in obese patients: minireview and clinical experience. Case Rep Dermatol 2019, 11 (Suppl 1).

23. Pinter A., Gerdes S., Barteczek P.: Cardiometabolic effects of secukinumab. J Am Acad Dermatol 2019, 81, Suppl 1, AB30.

24. Lee F.I., Bellary S.V., Francis C.: Increased occurrence of psoriasis in patients with Crohn's disease and their relatives. Am J Gastroenterol 1990, 85, 962-963.

25. Cohen A.D., Dreiher J., Birkenfeld S.: Psoriasis associated with ulcerative colitis and Crohn's disease. J Eur Acad Dermatol Venereol 2009, 23, 561-565.

26. Whitlock S.M., Enos C.W., Armstrong A.W., Gottlieb A., Langley R.G., Lebwohl M, et al.: Management of psoriasis in patients with inflammatory bowel disease: from the Medical Board of the National Psoriasis Foundation. J Am Acad Dermatol $2018,78,383-394$

27. Schreiber S., Colombel J.F., Feagan B.G., Reich K., Deodhar A.A., Mcinnes I.B., et al.: Incidence rates of inflammatory bowel disease in patients with psoriasis, psoriatic arthritis and ankylosing spondylitis treated with secukinumab: a retrospective analysis of pooled data from 21 clinical trials. Ann Rheum Dis 2019, 78, 473-479.

28. Fougerousse A.C., Perrussel M., Bécherel P.A., Begon E., Pallure V., Zaraa I., et al.: Systemic or biologic treatment in psoriasis patients does not increase the risk of a severe form of COVID-19. J Eur Acad Dermatol Venereol 2020, 34, e676-e679.

29. Coskun Benlidayi I., Kurtaran B., Tirasci E., Guzel R.: Coronavirus disease 2019 (COVID-19) in a patient with ankylosing spondylitis treated with secukinumab: a case-based review. Rheumatol Int 2020, 40, 1707-1716. 
30. Galluzzo M., Tofani L., Bianchi L., Talamonti M.: Status of a real-life cohort of patients with moderate-to-severe plaque psoriasis treated with secukinumab and considerations on the use of biological agents in the Covid-19 era. Expert Opin Biol Ther 2020, 20, 829-830.

31. Di Lernia V., Bombonato C., Motolese A.: COVID-19 in an elderly patient treated with secukinumab. Dermatol Ther 2020, 33, e13580.

32. Mugheddu C., Sanna S., Atzori L., Rongioletti F.: Safety of secukinumab treatment in COVID-19 affected psoriatic patients. Dermatol Ther 2021, 34, e14710.

33. Damiani G., Pacifico A., Bragazzi N.L., Malagoli P.: Biologics increase the risk of SARS-CoV-2 infection and hospitalization, but not ICU admission and death: real-life data from a large cohort during red-zone declaration. Dermatol Ther 2020, 33, e13475.

34. Liu Y., Zhang C., Huang F., Yang Y., Wang F., Yuan J., et al.: Elevated plasma levels of selective cytokines in COVID-19 patients reflect viral load and lung injury. Natl Sci Rev 2020, 7, 1003-1011.

35. Cafarotti S.: Severe acute respiratory syndrome-coronavirus-2 infection and patients with lung cancer: the potential role of interleukin-17 target therapy. J Thorac Oncol 2020, 15, e101-e103.

36. Pacha O., Sallman M.A., Evans S.E.: COVID-19: a case for inhibiting IL-17? Nature Rev Immunol 2020, 20, 345-346.

37. von Stebut E., Boehncke W.H., Ghoreschi K., Gori T., Kaya Z., Thaci D., et al.: IL-17A in psoriasis and beyond: cardiovascular and metabolic implications. Front Immunol 2020, 10, 3096.

Received: 11.06 .2021

Accepted: 25.10.2021

Otrzymano: $11.06 .2021 \mathrm{r}$.

Zaakceptowano: 25.10.2021 r. 